\title{
A Survey of Human Rights Abuses Among New Internally Displaced Persons Herat, Afghanistan
}

April 2002

\author{
A Briefing Paper by \\ Physiclans for Human Rights \\ Boston • Washington DC \\ Table of Contents \\ Executive Summary \\ Introduction \\ Background/Purpose of Study \\ Methods \\ Results \\ Testimonies \\ Conclusions \\ Recommendations
}

\section{Executive Summary}

The findings of this study indicate that abuses were committed on a widespread basis among Pashtun households in Western Afghanistan. Armed militias (primarily Uzbek forces) have used intimidation, extortion and committed abuses against civilians, primarily ethnic Pashtuns, including killings, beatings, shootings, disappearances,

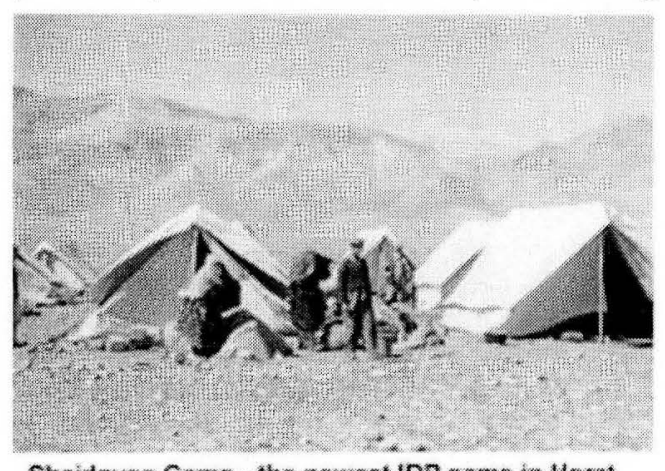

Shaidayee Camp - the newest IDP came in Herat with IDPs from five different western provinces. These are all IDPs since Sept. 11.

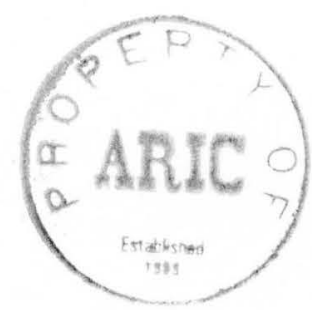
despite increased international assistance and humanitarian aid, lack of food distribution and the need for emergency assistance were the main reasons that people in Western Afghanistan left their home villages to go to Shaidayee IDP camp. In a time when reconstruction is the priority in Afghanistan, basic needs such as food, clean water, shelter, health care services, and security cannot be ignored, without placing many Afghans at further risk for dire health consequences.

The respondents in this study reported that at least one or more abuses had occurred in $8 \%$ of all households, $3 \%$ of Tajik households and $14 \%$ of Pashtun households. Abuses occurred in home villages in 10 districts in Ghor, Baghdis, and Faryab provinces. Sixty-eight percent of the abuses were attributed to Uzbek forces. The abuses among Pashtuns were $\sim 2-5$ times the number of reported abuses among other ethnic groups in Shaidayee camp. It is clear that in several instances the abusers were known to the respondents and that the abusers were primarily of Uzbek ethnicity. In one case, an Uzbek commander was involved in extortion from a Pashtun household, creating a question of whether or not other Uzbek commanders are complicit in these abuses. 


\section{Introduction}

The collapse of the Taliban regime in November 2001 gave the people of Afghanistan hope that after 23 years of war, the international isolation and human rights abuses that they suffered would come to an end. The Bonn agreement, the installation of the Interim Government, the future prospect of democratic reforms and the deployment of international security forces in Kabul, heralded a new Afghanistan and a promise of international support and cooperation. Yet, armed factional groups have continued to commit human rights abuses against civilian ethnic groups, especially in areas where there is little presence of international or local security. The findings of this report indicate that local Afghan forces of Uzbek ethnic origin appear to have systematically abused ethnic Pashtuns particularly in western districts that are primarily Pashtun villages. The study also shows that the primary reason people are fleeing their homes and seeking humanitarian assistance in the Shaidayee camp for internally displaced persons (IDP), is that food and emergency aid were not available in their home villages.

In April 2002, Physicians for Human Rights (PHR) surveyed 509 IDP households in Shaidayee Camp in Herat, Afghanistan. The study revealed that Pashtun families were two to five times as likely to be victims of human rights violations as nonPashtuns. While it is not clear how many of the abuses were directly ordered by local commanders, violations against ethnic Pashtuns were pervasive enough that commanders and local authorities are likely to be aware of them. Nonetheless, little has been done to insist upon order or to end persecution of the Pashtun. Predominantly Pashtun Afghans associated with the Taliban regime were guilty of many abuses against men, women, and children from minority ethnic groups, and in particular the Uzbeks and Hazaras. It appears now to be the case that some individuals as well as military figures are acting against Pashtun civilians by way of reprisal. Alternatively, some abuses may simply be opportunistic attacks to steal or look for the weakest within a community. Whatever the motivation of the perpetrators, however, the crimes against unarmed ethnic Pashtun families are human rights abuses that set the stage for further ethnic tension within Afghanistan - a development the country can ill afford.

\section{Background/Purpose of Study}

There are three main ethnic-based parties that control provinces, districts and villages in Northern and Western Afghanistan.1. These parties are supported by armed militias and include the Uzbek Junbish-iI Milly-yi Islami, the Tajik Jamiat-eIslami, and the Hazara Hizb-I Wahdet. There are other non-aligned armed Uzbek, Tajik and Hazaras in these areas as well.2

Civilians in both the Northern and Western regions of Afghanistan have reported human rights abuses in their districts of origin to non-governmental organizations (NGOs) and United Nations offices. These abuses include rape, harassment, extortion, land seizure, killings, disappearances, beatings, looting and intimidation. Many of these violations have been reported by civilians as reprisals against Pashtuns, the Afghan ethnic group most commonly associated with the Taliban regime.

Recently, the Afghan Interim Government appointed an independent commission to investigate alleged ethnically-based abuses against Pashtuns in Northern 
Afghanistan, which had been documented by Human Rights Watch. 3 However, the capacity of this commission to effectively address violence against Pashtuns in Northern and Western Afghanistan has been limited by the power and influence of the local commanders in these areas. Even with the removal of the commanders who are reportedly implicated in the abuses against Pashtuns in their communities, especially in Faryab, the violations continue under the watch of other commanders who were placed to protect Pashtun villages from such acts. 4

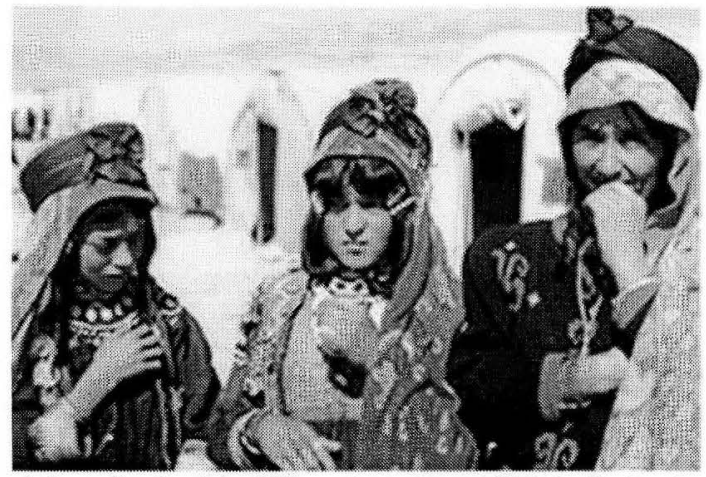

Internally displaced Timoni women waiting to find out whether it is safe to retum to their willages

Despite measures to protect civilian populations, over the last three months a large influx of long-term internally displaced persons (IDPs) have fled to the Herat province in Western Afghanistan from Ghor, Baghdis, Faryab, Farah, and Balkh provinces, and have settled in Shaidayee IDP camp on the outskirts of Herat city. According to UNHCR, many of the IDPs reported that they fled their home villages due to lack of food distribution and the need for emergency assistance. Others, especially Pashtuns, also reported that abuses had occurred in Pashtun villages in many Provinces in the Western Region.

In response to these anecdotal reports, Physicians for Human Rights (PHR) sent Lynn Amowitz, M.D., M.S.P.H., PHR's Fireman Health and Human Rights Fellow, to Western Afghanistan in April 2002 to scientifically assess alleged human rights abuses perpetrated in the Western region home villages of recently arrived IDPs to the Herat Province. This was Dr. Amowitz's seventh trip to the region. In Herat, she assembled a team of 48 local surveyors. The team completed a comprehensive survey of the entire New Arrivals section of Shaidayee camp. Physicians for Human Rights conducted a population-based survey to assess the prevalence of alleged human rights violations in the districts of origin. To provide insight into individual experiences of the abuses reported in the survey, PHR also conducted more detailed qualitative interviews (case testimonies) among survey subjects reporting abuses.

\section{Methods}

\section{Shaidayee Camp}

Shaidayee camp was originally established by UNHCR in October 1996 and as of March 27, 2002, had 4,588 registered families (25,149 individuals). 5 At the time of the study (March 29, 2002), 551 families were registered as "New Arrivals" (having arrived within the last three months) in Shaidayee camp. A section of the camp was opened for new arrivals on February 10, 2002 due to overcrowding of the more established IDP camps in the area including Mazlack and Rawza Bagh camps. 6

The camp, directly off of the main road going to the eastern districts of Karuch, Obeh, and Chesht-e-Sharif of Herat Province, is in the midst of a dry desert basin without any natural water source. Water is adequately supplied to the camp by chlorinated, hand pumped ground wells. Traditional pit latrines are used by adults, however, the children continue to defecate around the camp in some of the pits made by the removal of dirt for traditional housing. The International Organization of 
Migration (IOM) served as camp administrator. 7 . Médecins sans Frontières (Holland) assists on initial health screening of all new arrivals and health care for the camp population. Security is provided by the local commander Ismael Khan's militia, primarily at checkpoints at the beginning and end of the main road in front of the camp.

The older IDP section consists of traditional shelters made of sun-dried mud bricks. New arrivals have been given large IOM standard, white tents that have a zippered opening in both the front and back. All domiciles (mud huts or tents) are placed in a grid system and are well organized and mapped. Distribution centers for food and non-food items are scattered through the camp and easily accessed by dirt roads. The main road in front of the camp has a bus stop for buses coming and going to other provinces as well as into Herat city. A bazaar has been established along this road by some of the IDPs where fruits, vegetables, candy, music cassettes, clothes, and other various items are sold.

\section{Subjects}

Subjects of the PHR survey consisted of one female or male head of household who could most accurately provide information about the experiences of the entire household and had arrived in three months or less to Shaidayee camp.

\section{Sampling}

All 551 tents in the new arrival's section of Shaidayee Camp were surveyed. The new arrival's section was the furthest section of the camp from the main road and was just at the base of a chain of sandy foothills. IOM personnel assisted in the identification of this section and remained in the area for questions throughout the sampling.

\section{Survey Instrument}

The survey instrument used was developed by PHR. Domains of inquiry include demographics, reasons for leaving home districts, household composition, human rights abuse experiences, perpetrator information, and qualitative interviews.

Regarding experiences of human rights abuses, respondents were asked whether they or their family members had been killed, beaten, shot, raped, gang raped, forced to undress, stripped of clothing, detained for less than 24 hours, more than 24 hours, or whether family members had disappeared. For each abuse, respondents were asked where and when the abuse happened, the reason for the abuse, information about the perpetrator, what the perpetrator said during the abuse, if the respondent knew the perpetrator, and the ethnicity of the perpetrator.

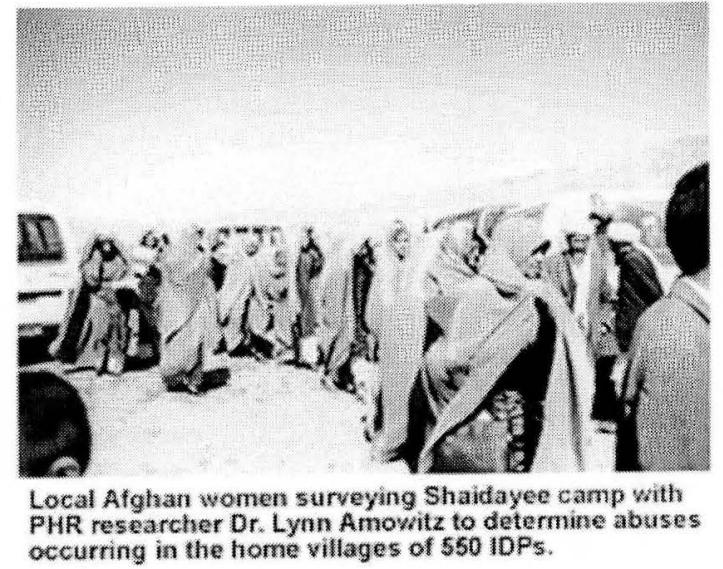

The survey was written in English and translated into Dari, the lingua franca of Afghanistan, and back translated into English. Human rights and medical (local, regional and international) experts reviewed the instrument for content validity.

\section{Interviews}

The survey was conducted by 48 local, 
female interviewers and 4 coordinators trained and supervised by PHR. Using Afghan women to do the interviews allowed female respondents to be part of the survey in this traditional society where men would not be allowed to privately interview women. Training included a combination of classroom teaching and supervised roleplay followed by field observation.

All interviews were conducted on March 29, 2002. Interviews were anonymous, lasted approximately 10-20 minutes, and were conducted in the most private setting possible. Verbal informed consent was obtained and participants did not receive any material compensation. Questionnaires were reviewed for completeness and for the correctness of recording after the interview by the researchers themselves, and then reviewed by the field coordinator at the end of the day.

\section{Human Subjects' Protection}

The research was reviewed and approved by an ad hoc group of individuals with expertise in clinical medicine, public health, bioethics, and international human rights research. In addition, permission for the study was granted by UN officials, camp administrators and from local community leaders in each area surveyed.

The research was conducted in accord with the Declaration of Helsinki, as revised in 2000.8 The identity of all subjects was anonymous to ensure protection and confidentiality and to reduce any potential adverse consequence to the participants. Verbal informed consent was obtained from all participants.

\section{Statistical Analysis}

Data was entered in a database for descriptive analysis. The quantitative data was analyzed using STATA statistical software. 9 For $2 \times 2$ cross tabulations containing cells with expected frequencies of less than 5 , statistical significance was determined using Fisher's exact test; Yates' corrected chi square was used for all others. Analysis of variance was used for statistical comparison of means and the Kruskal-Wallis test used for comparison of medians. For all statistical determinations, significance levels will be established at $p<0.05$.

\section{Results}

\section{Demoqraphics}

Of the 551 domiciles surveyed, $39(7 \%)$ were ineligible (arrived more than 3 months ago) for inclusion in the study. Of the remaining 512 domiciles, 509 (response rate: $99 \%$ interviews were completed. Three $(0.4 \%)$ of the households surveyed did not have a respondent present in the domicile after 2 attempts. The total number of household members living in the 509 domiciles sampled was 5,526.

Characteristics of the respondents are presented in Table 1. The average age of the respondents was 35 years of age. Fifty-two percent of respondents were female and $48 \%$ male. Seventy-eight percent of respondents were married, $16 \%$ widowed, $25 \%$ never married and $1 \%$ reported either being separated or divorced. Pashtun $(45 \%)$ and Tajik (40\%) were the most common ethnicity reported, however, Ayamaq, Jamshidy, Uzbek, Timoni, Arabic and Firos Kuhy were also reported (Figure 1). The mean number of days in the camp was 17; however, most IDPs left their home villages, on average, 45 days before arriving in the camp. Most IDPs were from Ghor $(34 \%)$, Baghdis $(33 \%)$, and Faryab $(27 \%)$, followed by Farah, Herat, Nimruz, and Balkh provinces. 
Table 1: Respondent Characteristics for New Arrivals in Shaidayee IDP Camp in Herat Afghanistan

\begin{tabular}{|c|c|}
\hline $\begin{array}{l}\text { Respondent Charactentictics } \\
\text { N=509 }\end{array}$ & $\begin{array}{l}\text { New Arrival 10pes } \\
\text { No. }(2 \%))^{2}\end{array}$ \\
\hline Mean age \pm SE, (range) & $35 \pm .57(14-90)$ \\
\hline $\begin{array}{l}\text { cender n=501 } \\
\text { Fombire } \\
\text { Male }\end{array}$ & $\begin{array}{l}262(-52) \\
259(48)\end{array}$ \\
\hline $\begin{array}{l}\text { Marital Status, } n=504 \\
\text { Married } \\
\text { Widowed } \\
\text { Never Married } \\
\text { Divorced/Separated }\end{array}$ & $\begin{array}{l}392(78) \\
81(16) \\
25(5) \\
6(1)\end{array}$ \\
\hline 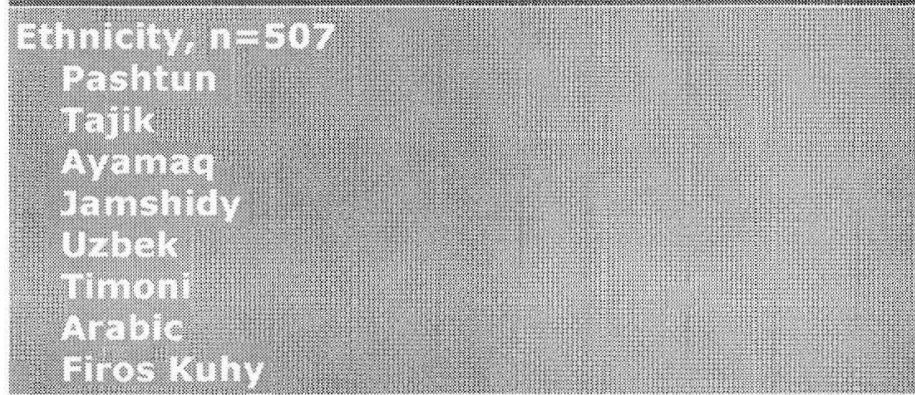 & $\begin{array}{l}251(45) \\
202(40) \\
41(3) \\
15(3) \\
5(1) \\
6(1) \\
6(1) \\
1(2)\end{array}$ \\
\hline No. days in camp, mean \pm SE (range). & $17 \pm .8(1-90)$ \\
\hline Wo. days leit home village, mean $=\mathrm{SE}$ (range) & $48=4(1-750)$ \\
\hline $\begin{array}{l}\text { Home Provinces } \\
\text { Chor } \\
\text { Baghdis } \\
\text { Faryab } \\
\text { Farah } \\
\text { Herat } \\
\text { Nimruz } \\
\text { Balkh }\end{array}$ & $\begin{array}{l}172(54) \\
170(33) \\
1.38(27) \\
21(4) \\
4(.8) \\
2(.4) \\
2(.4)\end{array}$ \\
\hline
\end{tabular}

*Values may not add up to $100 \%$ due to rounding 
Figure 1: Reported Ethnicity of New Arrival IDPs in

Shaidayee Camp

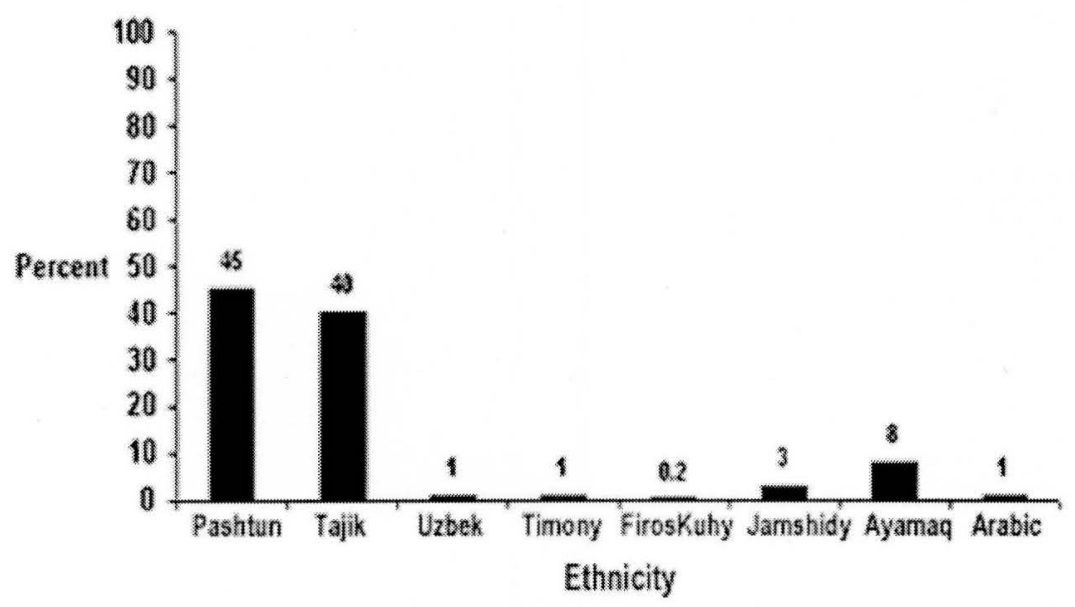

New arrivals were asked to rank the reasons that they came to the IDP camp. The most common primary reasons for coming to the IDP camp were no food distribution in the province $(77 \%)$, land seizure by Uzbek forces $(6 \%)$ and looting of households and valuables stolen ( $6 \%)$, followed by need of emergency assistance $(4 \%)$, drought $(4 \%)$, land seizure by Tajik forces $(0.6 \%)$, fighting in the area $(0.6 \%)$, being forced to leave by armed forces $(0.4 \%)$, fear of physical safety $(0.4 \%)$, and extortion $(0.2 \%)$.

The most common secondary reasons for coming to the IDP camp included the need for emergency assistance (56\%), no work opportunities (15\%), land seizure by Uzbek forces (8\%) and looting of households and valuables stolen (8\%). The remaining secondary reasons included no food distribution in the province $(6 \%)$, drought $(2 \%)$, fear of physical safety $(2 \%)$, fighting in the area $(1 \%)$, no health care facilities $(1 \%)$ and land seizure by Hazara forces $(0.5 \%)$.

Table 2: Most common reasons for coming to Shaidayee Camp

\begin{tabular}{|c|c|}
\hline Reason for coming to camp & $\begin{array}{l}\text { New Arrival } \\
\text { No. }(\%)^{*}\end{array}$ \\
\hline 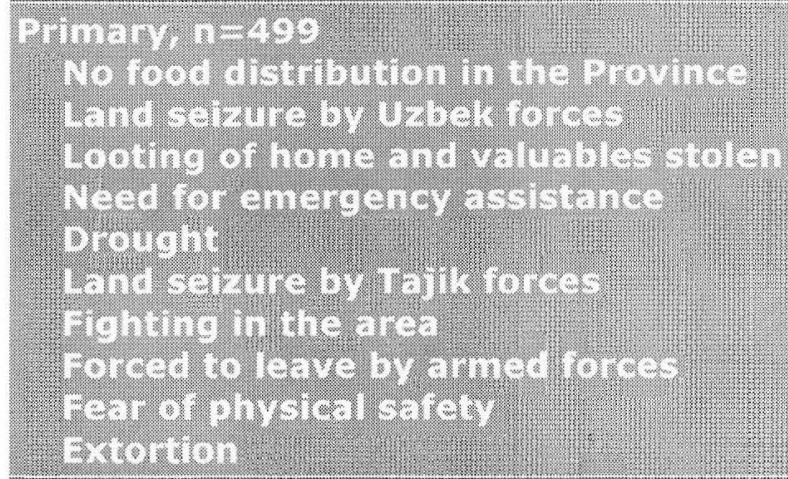 & 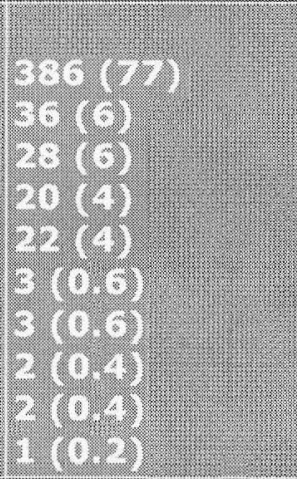 \\
\hline $\begin{array}{l}\text { Secondary, } n=219 \\
\text { Need for emergency assistance }\end{array}$ & $122(56)$ \\
\hline
\end{tabular}


Drought

Land seizure by Uzbek forces

Looting of home and valuables stolen

No food distribution in the province

Drought

Fear of physical safety

Fighting in the area

No health care facilities

Land seizure by Hazara forces

*Values may not add up to $100 \%$ due to rounding

\section{Abuses}

Characteristics of the reported abuses are presented in Table 3. Of all the households reporting abuses, $77 \%$ (33 of 43) were ethnic Pashtun (Figure 2). Overall, $8 \%$ of households reported one or more abuse among household members. Abuses among Pashtun households (14\%) was nearly double that of all households and 5 times that of Tajik households (3\%).

The abuses were most common among male family members ( $88 \%)$ with a mean age of 29 years. The abuses occurred primarily in home villages $(52 \%)$ or in transit to Shaidayee camp (19\%) and included killings (46\%), explosive ordinance or gunshot wounds $(25 \%)$, beatings $(23 \%)$, and disappearances $(4 \%)$. The most common reasons given for the abuse was "ethnicity" (44\%), although many could not identify a reason $(23 \%)$ or listed the reason as "other" $(11 \%)$. Uzbek forces were listed most often as the abuser (75\%) (See Figure 3 ). The provinces and districts where abuses were reported from are listed in Table 4.

Table 3: Characteristics of Reported Abuses Among IDP Households

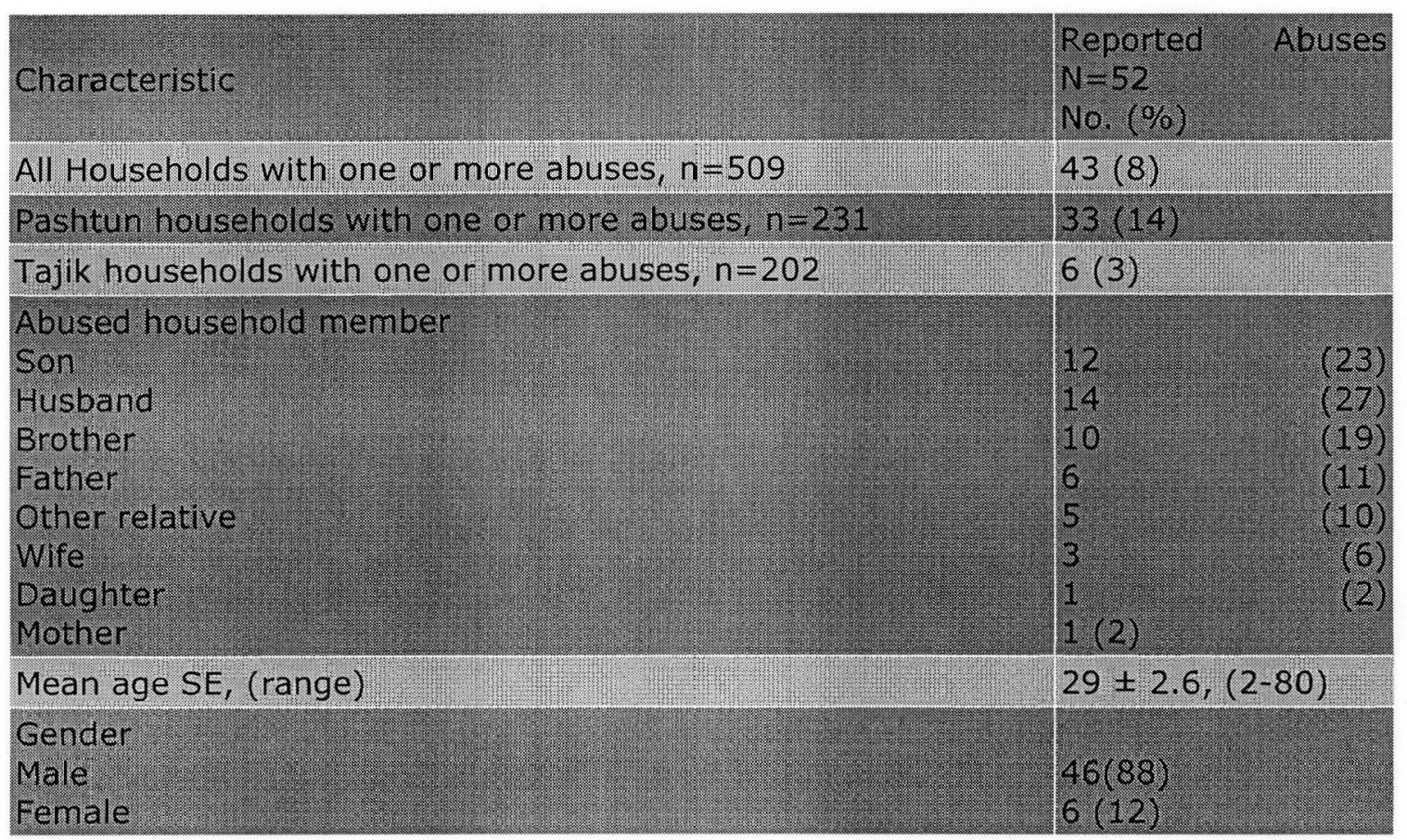




\begin{tabular}{|c|c|c|}
\hline $\begin{array}{l}\text { Place of Abuse } \\
\text { Home village } \\
\text { Transit to Shaidayee camp } \\
\text { Transit to other location } \\
\text { Shaidayee camp } \\
\text { Check point } \\
\text { Do not know }\end{array}$ & $\begin{array}{l}27 \\
10 \\
6 \\
4 \\
4 \\
1(2)\end{array}$ & $\begin{array}{r}(52) \\
(19) \\
(11) \\
(7) \\
(7)\end{array}$ \\
\hline $\begin{array}{l}\text { Abuse } \\
\text { Klled } \\
\text { Explosive ordinance, gunshot wound } \\
\text { Beaten } \\
\text { Disappearance } \\
\text { Gang rape }\end{array}$ & $\begin{array}{l}24 \\
13 \\
12 \\
2 \\
1 \\
1\end{array}$ & $\begin{array}{l}(46) \\
(25) \\
(23) \\
(4)\end{array}$ \\
\hline $\begin{array}{l}\text { Reason for Abuse } \\
\text { Ethnicity } \\
\text { Do not know } \\
\text { Accused of being a combatant } \\
\text { Other (unspecified) } \\
\text { Refused forced conscription }\end{array}$ & $\begin{array}{l}23 \\
12 \\
7(14) \\
6 \\
4(8)\end{array}$ & $\begin{array}{l}(44) \\
(23) \\
(11)\end{array}$ \\
\hline
\end{tabular}

Among households reporting abuses $(n=43), 88 \%$ of the respondents reported the ethnicity of the abuser as Uzbek. Fifty-six percent stated they knew the identity of the abuser and $5 \%$ could give the name of the commander and/or an accomplice.

Figure 2: Proportion Of Households Reporting Abuses By Ethnicity $(n=43)$

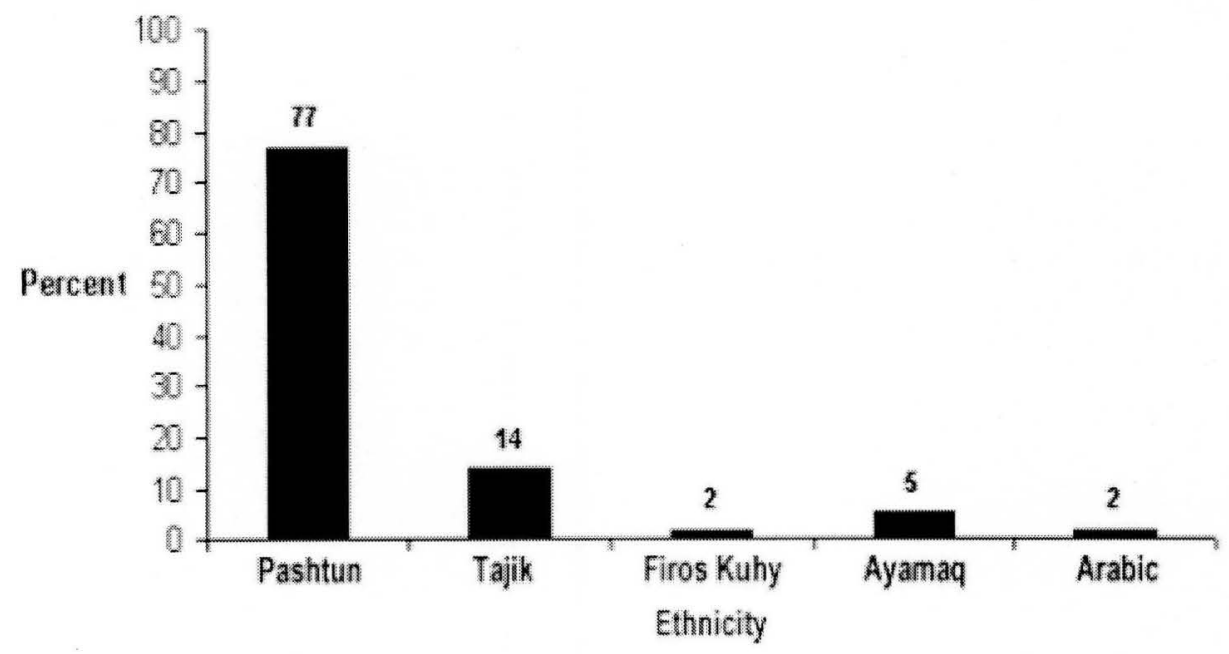


Figure 3: Proportion of Abuses Committed By Individual Abuser Groups

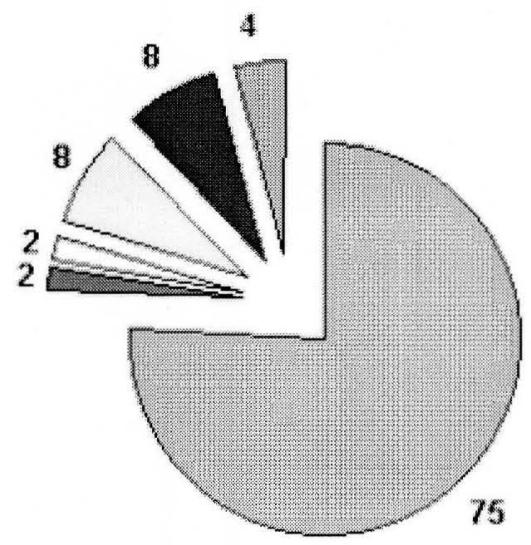

\begin{tabular}{|lll}
\hline$\square$ Uzbek Forces & $\square$ Hazara Forces & $\square$ Civilian \\
$\square$ Armed bandits & Unknown & $\square$ Other (unspecified)
\end{tabular}

Table 4: Provinces and Districts With Reported Abuses

\begin{tabular}{|c|c|}
\hline Provines & Districts \\
\hline enor & 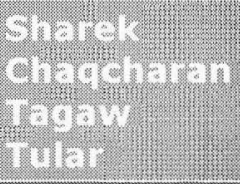 \\
\hline Baghots & $\begin{array}{l}\text { Ehornuad } \\
\text { jawand } \\
\text { eglagnaw }\end{array}$ \\
\hline 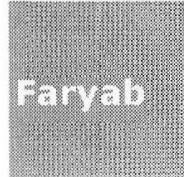 & 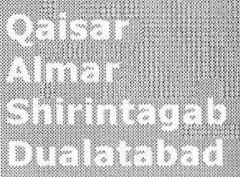 \\
\hline
\end{tabular}

\section{Testimonies}

In order to gain insight into individual experiences of the abuses reported in the survey, PHR also conducted more detailed qualitative interviews (case testimonies) among survey subjects reporting abuses. Willing respondents were given a chance to give a more detailed history of the abuse to the researcher and translator. Each of these qualitative interviews was recorded in a log and where possible, the exact words of the respondents were used to give expression to their individual experiences. Examples of killings, looting, sexual assault and other abuses are as follows:

\section{Killings}


Faryab Province, Qaisar district - Village of Sinshtak

24 year-old Pashtun male:

My brother was 15 or 16 years old. He was a farmer and had been married recently. He was small and had no beard and was plowing the land. During the time the Americans were bombing, he was approached by Uzbek soldiers. There were many witnesses and they told me that they blamed him for being a Talib or Al Qaeda. The people who did see the attack said that they beat him with guns and kicked him until he died. After they saw him being beaten, they fled and came back to find him dead. We were afraid so we did not collect his body and did not bury him. I had to come here and left him in the field.

I am also a farmer and have a wife and 1 small child. I came here because I was robbed by Uzbek soldiers 5-6 months ago, around the same time my brother was killed. They took everything; our camels, our donkey and money. I only had 400500,000 afghanis, 10 but they took all of that. Everyday they wrote a letter and said that we should pay 10,000 afghanis after we had paid everything we had. We had to sell our belongings to pay each day that the letter came. Sometimes, they would come for the money at our house. We had to pay them and make lunch for them as well. They would sit in our house until they were fed and got the money. I do not have the letter, when I left, I left very fast after my brother was killed and when I had no more money to pay the soldiers. We knew all of the soldiers in the area. The commander was Sachy and the man who came to our house to collect the money was called Fatollah. Everyone in the villages knew the soldiers but still they took everything.

\section{Faryab/Chilgazia district - Narkarkhana village \\ Pashtun woman:}

I am 30-35 years old, I am not sure which. I married my husband when I was around 10 years old and I have 8 children ages $15-26$. The Uzbek forces came to our village and beat my husband to make him give them money. He said he had no money so they beat him to death. I saw what happened. Seven or eight Uzbek soldiers that we did not know, came to our village and into our house. They beat him with the guns, feet and sticks. The children also saw them beat their father and ran. I told them we do not have money. Where should I get money to pay you so you do not beat my husband? They were speaking Farsi so I did not understand them. After my husband was dead, they left and did not do anything to me or the children

I walked so much to get here, my feet are swollen and hurting. They took my husband and have taken all of my animals so we had nothing left and we had to leave. We came walking but in Baghdis borrowed some money to come here by truck.

Faryab Province, Kutchi nomad in the Qaisar district 60 year-old Pashtun man, married with 3 children:

My brother died when my three nephews were very small so I have been caring for them and have been their father since he died. Three months ago, all three of them disappeared. One was brought to me and had a bullet hole in his head (the frontal 
area). The nephews were walking together and someone shot one in the head. The one who we found dead was 12 ; the 20 and 30 -year-old boys are missing. I went to the bazaar to find them to see if anyone saw what happened, but they just said they were taken. No one could tell me who took them or what they looked like. I do not know who killed them. They did not do anything wrong so I cannot know why someone should kill them. I came here because I was hungry and I could not work. I have no land, no sheep, so I came here slowly (1 month) to get aid.

\section{Faryab Province - Shirintigab District - Shourdia Village 25-year-old Pashtun woman, 5 children:}

My husband worked in Iran and had money. We were comfortable and did not need anything. He was a shopkeeper in the shop everyday until $7 \mathrm{pm}$. One month ago, at the end of the night, Uzbek forces came and entered the shop and brought him from the shop to the home. They wanted to take our sheep. I brought the Koran and said OK, take the sheep but do not kill my husband. They pushed the holy Koran, took the sheep and shot my husband. My husband was innocent but they shot and killed him. He was only 40 years old. We could not go to get the body or go to bury him. I had to flee with my children. I was afraid. The other villagers fled as well so I left with them. Now, just I sit here, I have no future. My children are small and cannot work. My oldest son is 11 years old. The children have been crying for 2-3 nights. Without my husband what does my life mean. Who is not missing my husband, he was a good man. I married him when I was aged 12 . I was the second wife. The other wife is older and is with her children in Faryab. I do not have money to go and bring them here.

\section{Faryab Province, Shirintagab District - Jaloya Village} 15-year-old Pashtun male:

We ( 6 family members) came to Shaidayee Camp one week ago because we had nothing and we were hungry. We walked from the Turkmenistan border to Torgomdy and then borrowed money to take a truck to here. In our village, we had a shop, sheep, and animals. One night ( $11 / 2$ months ago), my brother was kidnapped from the house. Four people from Dostum's forces came at the early morning Hazan (Call to prayer at $4 \mathrm{am}$ ) into our home and took my brother. They took him and all of our animals. I think they killed him because they were afraid he would come and ask for the animals back. (Crying) Two days later we found his body. He had three holes in his head and two in the chest. He died at 30 years old. We buried him before we left, but we left his body in the village without anyone to tend to his grave.

\section{Gang Rape}

Faryab Province, Dualat District - Shurdaria Village

Pashtun male:

I have three children ages 2, 4 and 8 years old. After the bombing and after the Talibs left, Uzbeks came to take control. They began shooting. They came in on horses in our village and kicked out all the men from the houses to another area. We had to spend the night in the desert and could not get to our houses. Our women and our children were in the houses alone. Since we could not get to them, they 
raped all the women in the village. Seven women in the village were raped...my wife was one of them. The children were in the house and heard the attack on their mother. The soldiers made the children stay in another room all night. The children told me that they heard their mother yelling and crying. They were in the house for the whole night. After I came back to the house when the soldiers had left, my wife told me that three men came in the house and raped her. I feel ashamed and afraid of the community, I cannot tell anything to my wife since she was innocent. I have not changed my policies towards my wife. My wife is very sad, and keeps saying that it is better to have been killed. We have continued to be intimate but I can tell she is hurting. My wife is in the hospital, her mother is with her. They did not have medicine here in the camp to help her.

This is not easy to talk about. I have not told anyone including the people in this camp. I am telling you because you will take my voice to those who can help to stop this. The world should know what is happening to Pashtuns. They (the soldiers) took everything; my wife, my dignity, I have nothing left. People should know.

\section{Conclusion}

The findings of this study indicate that abuses were committed on a widespread basis among Pashtun households in Western Afghanistan. Armed militias (primarily Uzbek forces) have used intimidation, extortion and committed abuses against civilians, primarily ethnic Pashtuns, including killings, beatings, shootings, disappearances, and gang rape. The findings also indicate that despite increased international assistance and humanitarian aid, lack of food distribution and the need for emergency assistance were the main reasons that people in Western Afghanistan left their home villages to go to Shaidayee IDP camp. In a time when reconstruction is the priority in Afghanistan, basic needs such as food, clean water, shelter, and health care services, and security cannot be ignored, without placing many Afghans at further risk for dire health consequences.

The respondents in this study reported that at least one or more abuses had occurred in $8 \%$ of all households, $3 \%$ of Tajik households and $14 \%$ of Pashtun households. Abuses occurred in home villages in 10 districts in Ghor, Baghdis, and Faryab provinces. Sixty-eight percent of the abuses were attributed to Uzbek forces. The abuses among Pashtuns were $\sim 2-5$ times the number of reported abuses among other ethnic groups in Shaidayee camp. It is clear that in several instances the abusers were known to the respondents and that the abusers were primarily of Uzbek ethnicity. In one case, an Uzbek commander was involved in extortion from a Pashtun household, creating a question of whether or not other Uzbek commanders are complicit in these abuses.

Afghans remain the United Nations High Commission for Refugees' largest single caseload of refugees in the world for the 20th year in succession.11 Recent figures indicate that there are more than 5 million Afghans remaining outside Afghanistan, 3 million in Iran, 2 million in Pakistan, and smaller numbers in other neighboring countries.12 Since March 1, 2002, more than 400,000 refugees had voluntarily returned from Pakistan and Iran to Afghanistan with the assistance of UNHCR, the Afghan Interim Administration and in collaboration with the governments of Iran, and Pakistan.13 In addition, the numbers of IDPs are estimated to be more than 1.2 million persons with only 30,000 of IDPs returning to home villages. 14 As the situation in Afghanistan changes, there will be strong pressure from the neighboring 
countries to repatriate refugees back to Afghanistan even if the refugees are uninformed about the humanitarian situation in their home villages. Such large movements of refugees may create a larger IDP problem. With continued drought, reported shortages of food in many provinces, 15 inadequate tertiary health care services in more than 23 of 31 provinces, a large influx of repatriated refugees will create a more difficult humanitarian situation for the United Nations and International assistance providers and may place the most vulnerable populations, especially women, at a higher risk for devastating health consequences such as maternal mortality which has been reported to be one of the highest in the world.16

\section{Recommendations}

1. The U.S. government, the international community, and UNAMA (UN Assistance Mission in Afghanistan), should support the Afghan Interim Government's request for expansion of the International Assistance Security Force (ISAF) beyond Kabul, particularly in those areas which are vulnerable to ethnically-based human rights violations.

2. Humanitarian aid providers (UN, international organizations and nongovernmental organizations)should ensure that adequate food distribution, basic/emergency needs and humanitarian support are in place in Herat, Faryab, Ghor, Baghdis, Farah, and Balkh Provinces prior to the return of IDPs.

3. The UN, international organizations and non-governmental organizations should meet with Afghan Interim Government officials and local leaders and forces to address and stop all persecutions and intimidation. Additionally, all those participating in the provision of humanitarian assistance and reconstruction efforts should be urged to monitor and report all human rights violations against returning refugees or IDPS to UNHCR protection officers. Violations against Afghan civilians who are not IDPs or refugee returnees should be reported to UNAMA representatives.

4. The perpetrators should be made held accountable for abuses.

5. The international community should work with local leaders and the Interim Government to ensure the formation of the human rights commission as prescribed by the Bonn agreement and the establishment of rule of law according to internationally accepted standards.

\section{Notes}

1. Human Rights Watch, Afghonkstan: Pavino for the Talban's Crmes, pp 4-5, 4749. Retrieved on April 17, 2002.

2. $I d$, supra 1

3. $I d$, supra 1

4. Id, supra 1

5. International Organization for Migration statistics given to PHR by Danny Gill, Senior Operations Officer, March 28, 2002.

6. Id, supra 4

7. IOM suspended assistance in early May 2002 to tens of thousands of Afghans living in camps in the west and north of the country because donor countries had not provided the necessary funds. Reuters, May 7, 2002

8. World Medical Association. Declaration of Helsinki: Ethical Principles for Medical Research Involving Human Subjects. 5th rev. ed. Edinburgh, Scotland: World Medical Association; 2000.

9. STATA 5.0 (Intercooled) for Windows. College Station TX.: STATA Corporation; 
10. Equivalent to $\sim 14-18$ US dollars

11. United Nations High Commission for Refugees (UNHCR), State of the World's Refugees Annual Report 2000; Accessed May 2, 2002.

12. United Nations Development Program Afghanistan, Needs Assessment Report: V. Social Protection, Health and Education; 2001; Accessed February 14, 2002.

13. United Nations High Commission for Refugees (UNHCR), UNHCR brieting notes: Afohanistan, EU April 30, 2002, Accessed May 2, 2002.

14. Afghanistan Information Management Service (AIMS), DP Statistics Aggregated at the Province Level, Accessed May 2, 2002.

15. United Nations Economic and Social Council: Report of the Secretary General, Commission on the Status of Women; 46th Session March 2002. Geneva, Switzerland, United Nations document E/CN.6/2002/5 (Advance Unedited).

16. $I d$, Supra 14

(C) 2002 Physicians for Human Rights

All rights reserved.

Physicians for Human Rights (PHR) promotes health by protecting human rights. Using medical and scientific methods, we investigate and expose violations of human rights worldwide and we work to stop them. We support institutions that hold perpetrators of human rights abuses, including health professionals, accountable for their actions. We educate health professionals and medical, public health and nursing students and organize them to become active in supporting a movement for human rights and creating a culture of human rights in the medical and scientific profession. PHR has pioneered the use of epidemiological health and human rights instruments to study health and human right abuses.

Physicians for Human Rights has conducted groundbreaking studies of women's health and human rights in Afghanistan. Long before the world was seized with the conduct of the Taliban regime, PHR undertook survey research of women's health and human rights, first in a 1998 report, The Taliban's War on Women, and most recently in a 2001 report, Women's Health and Human Rights in Afghanistan. The report can be viewed in full on our web site. The latter survey of about 750 women showed the stunning deterioration of women's health, both physical and mental health, under the Taliban regime, their attitudes about human rights, and their perceptions of their health needs. PHR's data have been cited repeatedly by the media, government officials and non-governmental organizations in plans to meet the needs of Afghan women in the post-war environment.

In January 2002, PHR also released a report on Conditions at Shebarghan Prison, northern Afghanistan. The report demanded that action be taken to ensure security across Afghanistan. In April 2002 PHR released a Preliminary Assessment of Alleged Mass Gravesites in the Area of Mazar-I-Sharif, Afghanistan. This report calls for the protection by the Interim Administration of Afghanistan and the international community of all alleged mass grave sites. 
Physicians for Human Rights, "A Survey of Human Rights Abuses Among New Internally Displaced Persons -Herat, Afghanistan" (April 2002) available at: http:/www.phrusa.org/research/afghanistan/report idp.html

This study argues that Pashtun households in Western Afghanistan have been subject to systematic human rights abuse since the fall of the Taliban.. Armed militias (primarily Uzbek forces) have used intimidation and extortion and committed abuses against civilians, primarily ethnic Pashtuns, including killings, beatings, shootings, disappearances, and gang rape. As well as documenting this, the study also argues that IDPs need improved access to food and emergency assistance in order to avoid dire health consequences. 